\title{
Decision Making in a Human Population Living Sustainably
}

\author{
JOHN S. HICKS, ${ }^{*}$ MARK A. BURGMAN, ${ }^{\circledR}$ \JULIAN N. MAREWSKI, † FIONA FIDLER, ${ }^{*}$ \\ AND GERD GIGERENZER $†$
}

*Australian Centre of Excellence for Risk Analysis, School of Botany, University of Melbourne, Parkville 3010, Australia †Center for Adaptive Behavior and Cognition, Max Planck Institute for Human Development, Berlin, Germany

$\ddagger$ Faculty of Business and Economics, Department of Organizational Behavior, University of Lausanne, Lausanne, Switzerland

\begin{abstract}
The Tiwi people of northern Australia bave managed natural resources continuously for 6000-8000 years. Tiwi management objectives and outcomes may reflect bow they gather information about the environment. We qualitatively analyzed Tiwi documents and management techniques to examine the relation between the social and physical environment of decision makers and their decision-making strategies. We bypothesized that principles of bounded rationality, namely, the use of efficient rules to navigate complex decision problems, explain bow Tiwi managers use simple decision strategies (i.e., beuristics) to make robust decisions. Tiwi natural resource managers reduced complexity in decision making through a process that gathers incomplete and uncertain information to quickly guide decisions toward effective outcomes. They used management feedback to validate decisions through an information loop that resulted in long-term sustainability of environmental use. We examined the Tiwi decision-making processes relative to management of barramundi (Lates calcarifer) fisheries and contrasted their management with the state government's management of barramundi. Decisions that enhanced the status of individual people and their attainment of aspiration levels resulted in reliable resource availability for Tiwi consumers. Different decision processes adopted by the state for management of barramundi may not secure similarly sustainable outcomes.
\end{abstract}

Keywords: adaptive management, aspiration levels, bounded rationality, satisficing, simple decision strategies, sustainable management, Tiwi

Toma de Decisiones en una Población Humana que Vive Sustentablemente

Resumen: Los Tiwi del norte de Australia han manejado sus recursos naturales continuamente durante 6000-8000 años. Los objetivos y resultados del manejo Tiwi pueden reflejar como obtienen información acerca del ambiente. Analizamos cualitativamente el ambiente social y físico de los tomadores de decisiones $y$ de sus estrategias de toma de decisiones. Partimos de la bipótesis de que los principios de la racionalidad limitada, particularmente el uso de reglas eficientes para resolver problemas de decisión complejos, explican como los manejadores Tiwi utilizan estrategias de decisión simples (i. e., heurísticos) para tomar decisiones robustas. Los manejadores Tiwi de recursos naturales redujeron la complejidad de la toma de decisiones mediante un proceso que recopila información incompleta e incierta para guiar decisiones rápidamente bacia resultados efectivos. Utilizaron retroalimentación de manejo para validar las decisiones mediante una espiral de información que resultó en la sustentabilidad a largo plazo del uso ambiental. Examinamos los procesos de toma de decisiones de Tiwi en relación con el manejo de pesquerías de barramundi (Lates calcarifer) y lo contrastamos con el manejo de la agencia gubernamental. Las decisiones que resaltaron el estatus de individuos y el logro de sus niveles de aspiración resultaron una fuente confiable de disponibilidad para consumidores Tiwi. Es posible que los procesos de decisión diferentes adoptados por el estado para el manejo de barramundi no aseguren resultados sustentables similares.

Palabras Clave: estrategias de decisión simples, manejo adaptativo, manejo sustentable, niveles de aspiración, racionalidad limitada, satisfacción, Tiwi 


\section{Introduction}

Most management and environmental decisions are based on fragmented, anecdotal, and incomplete information. The principles of adaptive management suggest that managers should keep their decision options open, gather data to discriminate among competing explanations of biological processes, and test whether alternative management strategies achieve objectives (Linkov et al. 2006; Lyons et al. 2008). However, there are few examples of the successful application of these principles (Walters \& Holling 1990; Keith et al. 2011). In practice, managers often establish operational processes that are difficult to change before the adaptive-management cycle can be iterated.

Information-gathering processes and the aspirations of those making decisions influence decision making. Many natural resource managers define the utility of a decision in terms of yield, revenue, or some other quantitative ecological measure, and then select the option with the greatest expected value (e.g., Costello \& Polasky 2008).

Until recently, this maximization approach dominated the management of fisheries worldwide (Punt \& Hilborn 1997). The idea is that people decide on a management action (e.g., which fish to catch) by assessing the expected value of the various options available to them. For example, barramundi (Lates calcarifer) are an important cultural and food resource for many people in northern Australia. A person may assess fishing barramundi versus other species by weighting the utilities of these options (e.g., the net revenue from fishing barramundi vs. the revenue from fishing other species) on the basis of their probability of occurrence (e.g., the probability of gaining the revenues associated with barramundi vs. other fishes). A rational decision maker would try to maximize benefits by choosing the option with the greatest expected value.

Some alternative strategies for managing natural resources do not rely on maximization approaches (Punt \& Hilborn 1997), for example, adaptive management and ecosystem management (Holling 1978; Smith et al. 2007). These approaches have been applied in many contexts, including in the management of harvested populations (Nichols et al. 2007).

\section{The Theory of Bounded Rationality}

When people make decisions, they are limited by available information, the cognitive limitations of their minds, and the limited time they have to make a decision. The theory of bounded rationality recognizes these limitations and suggests that people often make decisions to satisfy basic aspirations rather than to optimize the expected value of the outcomes (Simon et al. 1958; Simon 1978), especially when there is great uncertainty in observations and causal relations. For instance, Simon proposed that people follow a simple "satisficing strategy," one that is sufficient to achieve a goal, rather than one that is optimal (Simon 1991; Gigerenzer \& Selten 2001).

According to Simon and other proponents of bounded rationality theory, optimization is rarely possible in the real world. In most practical circumstances, humans have to face uncertainty rather than situations where all risks are known or can be calculated. If one nevertheless tries to calculate the optimal solution, optimal solutions are often fragile in the sense that if estimates of expected outcomes are slightly wrong, then benefits may be much less than expected. A satisficing strategy requires ways of making decisions that aim to deliver specified minimum satisfactory goals, thereby minimizing the effects of uncertainty on outcomes. For example, when assessing whether a particular fish species may be harvested, the decision maker assesses whether there are sufficient fish to satisfy the immediate needs of the individuals making the request (their aspirations). If there is an appreciable chance that satisfactory goals will not be met, the decision maker may deny access to this species and suggest an alternate resource.

To find such satisfactory solutions, people use a class of simple rules and strategies, termed heuristics (or rules of thumb). Heuristics are "any principle or device that contributes to the reduction in the average search to solution" (Simon et al. 1958: p. 22).

Ideas of satisficing and decision heuristics provide a foundation not only for the notion of bounded rationality as Simon developed it, but also for a host of successful applications and theoretical extensions. One of these extensions, the "fast-and-frugal heuristics" framework (Gigerenzer et al. 1999), could be used to explain how and when human reliance on simple decision strategies (i.e., fast-and-frugal heuristics) can result in behavior that reflects adaptive-management principles. This framework assumes not only that rationality is bounded, but investigates the degree to which people's decision strategies are ecologically rational. Being ecologically rational means that a strategy exploits the structure and attributes of the context in which a decision is made; that is, decision strategies account for the so-called task environment (Gigerenzer et al. 1999), the extent and reliability of information, predictable environmental patterns, and the availability of alternatives.

For example, there is evidence that people exploit the task environment to make judgments about future events or unknown quantities by relying on patterns such as the frequency with which they have encountered information about a particular topic before (Marewski et al. 2010b; Marewski \& Schooler 2011). For instance, the frequency with which one hears the name of an object (e.g., the frequency of hearing the name of a clan member) might serve as a cue to make inferences about the associated object (e.g., how powerful that clan member is). In doing so, people can make relatively accurate 
estimates and fast decisions (Marewski et al. 2010a; Gigerenzer et al. 2011). By exploiting the task environment, these simple decision strategies can render decision making faster and more accurate than more complex techniques that require more information, such as those used in machine learning, artificial intelligence, and optimization approaches (see Gigerenzer \& Brighton 2009 for an overview).

Despite these developments, the field of resource management is, arguably, still dominated by maximization approaches. The natural resource management strategies of the Tiwi people of northern Australia illustrate an alternative, successful, approach to conservation.

\section{The Tiwi}

The Tiwi people inhabit 760,000 ha, primarily on 2 large islands-Bathurst and Melville islands, off the northern coast of Australia's Northern Territory. They also own and have access to 5 relatively large and a number of smaller islands covering 40,000 ha (total management area $800,000 \mathrm{ha}$ ). Rising sea levels separated these islands (highest elevation $200 \mathrm{~m}$ ) from mainland Australia between 8000 and 6000 years ago (Peterson \& Taylor 1998).

Tiwi were isolated until interaction with Indonesian, Dutch, British, and possibly Portuguese sailors in the 17 th century. The Tiwi population size was estimated to be around 1500 in 1910 (Peterson \& Taylor 1998) and 2000 during the past 100 years (Clancy 2009 TLC Records). Tiwi consumed fish, birds, macropods, reptiles, wild honey, and yams and other vegetables (Hart 1930). Tiwi thus were self-sustaining for at least 6000 years (Bowdler 1995; Sim \& Wallis 2008). Observations by early explorers (Swaardecroon et al. 1859; King 1818) confirm that these resources were readily available to Tiwi. More detailed studies by social scientists living among the people and able to converse in Tiwi have provided insights into governance and management techniques (Hart 1930; Pilling 1978; Venbrux 1995).

Tiwi culture lends itself to a study of sustainable resource management for at least 2 reasons. First, the Tiwi have not constructed a language of numbers and have no language for probabilities-concepts that are fundamental to maximization approaches that assume decision makers weight the utilities of the various options available to them (e.g., revenues of fishing different species) on the basis of the probabilities of occurrence (e.g., Linkov et al. 2006). The Tiwi process of gathering and representing information for decisions instead relies on simply communicating whether resources are satisfactory for immediate needs-a strategy that is consistent with the aspiration levels sought through the satisficing heuristic.

Second, decision-making processes of the Tiwi differ from those of Australia's Northern Territory government. Government uses more conventional maximization ap- proaches that rely implicitly on estimates of the size and productivity of harvested populations.

We sought to describe Tiwi decision processes and relate them to the theory of bounded rationality. We contrasted Tiwi sustainable resource management with more conventional resource management prescriptions. Finally, we considered why the Tiwi management strategies deliver long-term sustainable resource management.

\section{Methods}

We used 4 primary sources of evidence to explore Tiwi decision-making strategies. The first source was the large body of scientific and other relevant literature (articles published between 1705 and the present, many of which appear in Literature Cited). We focused on the evidencebased conclusions of scientists whose fieldwork with the Tiwi exceeded 2 successive years (Davis 1983; Venbrux 1995; Wightman 2001) or, in 3 instances, was over 30 successive years (Hart 1926-1960, Pilling 1928-1978, and Goodale 1966-1998).

Second, we used decisions over 35 years (1977-2012) documented in Tiwi Land Council (TLC) proceedings collected by the Australian National Archives, Canberra, and compiled into 29 annual volumes. We supplemented TLC proceedings with 32 TLC Annual Reports 1978-2011 held by the Parliamentary Library of the Parliament of Australia, Canberra.

The third source was 26 years of personal, direct, continuous, daily interactions, and observations by one of us (J.H.) with 3 generations of the 40 Tiwi Big Men who represented all Tiwi landowning groups and their families (1986-2012). Tiwi Big Men have particular knowledge of resources, are deferred to in decision making, and govern access to and use of natural resources allocated among 100 or so families occupying 8 geographical regions across the islands. Deference to this authority is enforced by strict behavioral rules and penalties. We also refer to these individuals as the Tiwi natural resource managers. Their status and skills are personal assets that cannot be inherited or bequeathed. Each generation finds, tests, and validates their Big Men through youth training (over 8-12 years) and tests their abilities within families prior to participation at communal forums. The Tiwi community accords these individuals elevated social status. The prestigious status of resource managers is reinforced by the availability and maintenance of resources under their stewardship.

Fourth, we used records of discussions and resource management decisions collected in poems, songs (many contained in over 300 booklets published by the Nguiu Literature Centre, Bathurst Island), and notes of boards, committees, and forums owned by the Tiwi Health Board, Tiwi Education Board, Tiwi Training and Employment 
Board, Tiwi Land and Marine Rangers, Tiwi College, and the 24 private corporations that have been developed and sustained by the Tiwi people.

On the basis of a qualitative assessment of the data, we constructed an informal model of Tiwi decision making. Our model reflects some recent developments in decision theory. Specifically, we documented current Tiwi resource management procedures and explored their relation with bounded rationality and information-collection processes.

To illustrate the model, we considered management of barramundi, a major food source. Management of this resource is an increasing source of conflict between different interest groups in the Tiwi islands (Northern Territory Government Department of Resources 2010). We contrasted information gathering and decision-making procedures of Tiwi decision makers and other fisheries managers.

There is no guarantee in qualitative analyses that biases in the examination of materials do not exist. Therefore, our objective was not to present a fully developed and validated theory of Tiwi sustainable resource management. Rather, our results represent an effort to create hypotheses that may be tested subsequently. Thus, although there is no direct tie to structured data, our qualitative assessment of the sources outlined above has generated a testable, relevant, and valid model (Huberman \& Miles 2002).

\section{Results}

Results of detailed anthropological and ethnographic studies over the past 100 years (Hart 1930; Goodale 1971; Venbrux 1995) show in general that the Tiwi aspire to prestige and influence. For example, Hart and Pilling (1960) note prestige and influence dominate Tiwi political processes. Goodale (1971) suggest that all Tiwi strive for personal achievement. Venbrux's (1995: p. 25) observations confirm these earlier conclusions.

Our direct observations and documentary analyses indicate that among the Tiwi, accruing surplus food enhances prestige. Quantitative analysis of adjacent mainland aboriginal households at Fitzroy, Daly River, and Pine Creek indicate that over two-thirds of commonly harvested species, including barramundi, are not consumed exclusively by the households that harvest them (Jackson et al. 2011). Wightman (2001) describes how cooking and distributing food are organized by Tiwi. The hunter is obliged to cook while the prestigious landowner supervises cooking and is offered the best cut. Surplus barramundi harvests accrue prestige to a Tiwi as a provider beyond the person's immediate family. Surplus is possible only if the land manager (the responsible Big Man) has been able to manage harvest activities to sustainable levels; and he can only do this by gathering information on the current status of the fish population and by applying cultural compliance measures that restrict access and use.

Permission and access rights are exercised within complex Tiwi governance and risk-management structures. Environmental management decisions must respect relationship bonds. For example, the most skilled fishing partners may not be granted permission to fish if they do not satisfy complex relationship priorities. Surplus harvests reinforce relationship bonds. For instance, sharing a fish catch with culturally distant friends, without first providing for more immediate family, can invite trouble for those caught doing it (M. Puruntatameri 1995 TLC records). The model we propose to represent the simple, efficient, and sustainable system of resource management used by Tiwi managers creates a feedback loop in which the status of managers encourages them to make decisions to ensure the ongoing availability of critical resources that satisfy vital needs (Fig. 1).

Resources are subject to access that can be granted or denied. For example, a family used axes to cut trees (an action for which they had not sought permission from the responsible Big Man) instead of climbing trees for foods and fruit. This action required meetings of managers (Pilling 1958) and the presentation of arguments. The community reached a consensus on legal sanctions that resulted in the family's prestige being diminished (Table 1). Penalties included having their authority over harvest rights for other resources being allocated to another family group (C. Kalippa, 2009 TLC records). The ideal strategy for any Tiwi manager (Big Man) is to accumulate ongoing prestige and influence by ensuring the availability of the resources under his control.

In the Tiwi management system, experienced decision makers "... reassess the situation every time new and relevant information comes to them. This leads to a

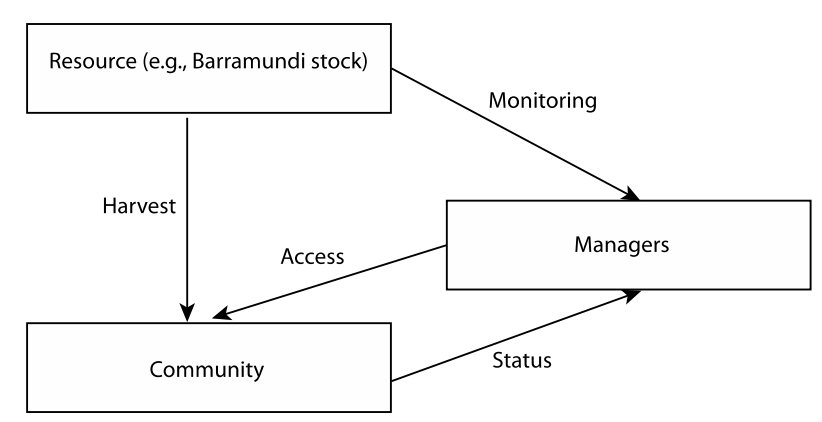

Figure 1. Management system employed by Tiwi natural resource managers. Managers monitor the status of resource stocks, advise the community, and grant access. Harvest information validates the manager's knowledge. The role of manager is prestigious and reliable managers are afforded elevated status. Arrows reflect the flow of information between the system elements. 
Table 1. Sample of evidence illustrating the decision-making system for sustainable resource management outlined in Fig. 1.

\begin{tabular}{|c|c|c|}
\hline Decision process & Quotations, statements, and observations* & Source \\
\hline \multirow[t]{7}{*}{ Access and sanctions } & $\begin{array}{l}\text { Many knew where the large mud mussels grow. } \\
\text { But J. said others cannot go without permission. }\end{array}$ & Wightman (2001): 69 \\
\hline & $\begin{array}{l}\text { We must protect your own land. It is risky for other people to go } \\
\text { without permission. }\end{array}$ & $\begin{array}{l}\text { W. Kerinaiua, } 2010 \text { TLC (Tiwi } \\
\text { Land Council) records }\end{array}$ \\
\hline & $\begin{array}{l}\text { C. and P. traveling together through X.'s land when P. decided to } \\
\text { burn the grass. C. distanced himself from P. who was later } \\
\text { punished for youthful disrespect. }\end{array}$ & Pilling (1958): case 59 \\
\hline & $\begin{array}{l}\text { T. arrived and found } 4 \text { blackened saplings connected by string. } \\
\text { Nobody must pass. He did and was banished from that land } \\
\text { forever. }\end{array}$ & Venbrux (1995): 59 \\
\hline & $\begin{array}{l}\text { Cycad nuts collected by men traveling through another's land. Fight } \\
\text { ensued. Illegal resource exploitation punished and prestige } \\
\text { maintained. }\end{array}$ & Pilling (1958): case 43 \\
\hline & $\begin{array}{l}\text { Have to see M. at Snake Bay if you want to fish here. They not there } \\
\text { now. Have to come back when they are and ask. }\end{array}$ & $\begin{array}{l}\text { B. Pupungamirri, } 1983 \text { TLC } \\
\text { records }\end{array}$ \\
\hline & $\begin{array}{l}\text { If you want to get geese from Puntjalnu, ask Puti who is the boss; or } \\
\text { gaint clam from Maranga you must ask the leader, U., the Big Man. }\end{array}$ & Pilling (1958): 48 \\
\hline \multirow[t]{6}{*}{ Status and reward } & $\begin{array}{l}\text { Only clever Tiwi know all the plants and animals. They are Big Men. } \\
\text { Women too. }\end{array}$ & $\begin{array}{l}\text { J.B. Pupungamirri, } 2001 \text { TLC } \\
\text { records }\end{array}$ \\
\hline & A dominant Big Man devoted his adult life to accumulating wives. & Cook (1994): 16 \\
\hline & $\begin{array}{l}\text { Ceremonial foods, yams, and most meats and fish, together with } \\
\text { legal sanctions relied upon men with recognized privilege. }\end{array}$ & Pilling (1978): 89 \\
\hline & $\begin{array}{l}\text { Power and prestige is gained by Tiwi Big Men by utilizing resources } \\
\text { to manipulate kinship relationships. }\end{array}$ & Goodale (1971): 337 \\
\hline & $\begin{array}{l}\text { Prestige and influence accrues to those with best knowledge of } \\
\text { growth, seasonal variations, and best harvest time. }\end{array}$ & Wightman (2001): 18 \\
\hline & $\begin{array}{l}\text { Male leaders (Big Men) can declare a new rule. T. gained general } \\
\text { approval for a new rule and his right to punish breaches was not } \\
\text { disputed. }\end{array}$ & Pilling (1958): 44 \\
\hline \multirow[t]{6}{*}{ Harvest (validation) } & $\begin{array}{l}\text { Up to } 300 \text { Tiwi attend ceremony. They come from other Tiwi } \\
\text { regions. }\end{array}$ & Davis (1983): 12 \\
\hline & $\begin{array}{l}\text { When you go to ceremony you can get ochre and see the country } \\
\text { belonging to other people. No problems. They all want Magpie } \\
\text { Geese when they come here. }\end{array}$ & $\begin{array}{l}\text { M. Wonaeamirri, } 2003 \text { TLC } \\
\text { records }\end{array}$ \\
\hline & $\begin{array}{l}\text { Activity within households may have occupied up to } 40 \text { weeks of the } \\
\text { year leaving } 12 \text { or so weeks for collective activity and ritual } \\
\text { outside the household. }\end{array}$ & Hart et al. (1988) \\
\hline & $\begin{array}{l}\text { We must get dugong, turtle, and fish. Buffalo too for people coming } \\
\text { for ceremony. Big shame for us without the food for visitors. }\end{array}$ & $\begin{array}{l}\text { J. Tipungwuti, } 1995 \text { TLC } \\
\text { records }\end{array}$ \\
\hline & $\begin{array}{l}\text { On the bark are marks for sponges on the rocks, crocodiles, turtles, } \\
\text { octopus, and crabs near the Imalu Creek. People know what's } \\
\text { there. }\end{array}$ & Davis (1983): 105 \\
\hline & $\begin{array}{l}\text { I put mussels in the basket and came back and told everybody. "Look } \\
\text { what I brought from Wulinto. Plenty of Mussels." }\end{array}$ & $\begin{array}{l}\text { J. Puruntatameri, } 1981 \text { TLC } \\
\text { records }\end{array}$ \\
\hline \multirow[t]{6}{*}{ Monitoring } & $\begin{array}{l}\text { The mimosa is flowering. Now the terns will arrive, and their eggs } \\
\text { will be ready to harvest. }\end{array}$ & C. Kalippa, 2009 TLC records \\
\hline & $\begin{array}{l}\text { Now is not the time for turtle. The big moon brings crabs up on the } \\
\text { high tide. We get crabs today. }\end{array}$ & $\begin{array}{l}\text { W. Kerinaiua, } 2010 \text { TLC } \\
\text { records }\end{array}$ \\
\hline & $\begin{array}{l}\text { The } 3 \text { main seasons each have recognizable variations, all with } \\
\text { flowerings that signal, for example, when possums are fat because } \\
\text { they feast on such flowers. }\end{array}$ & Wightman (2001): 144 \\
\hline & The Emerald Dove calls to signal it is time to harvest Muranga yams. & Wightman (2001): 44 \\
\hline & $\begin{array}{l}\text { We need to restrict the tern eggs this season. Too many outsiders } \\
\text { getting them. Not so many terns arrived this year. }\end{array}$ & 1998 TLC minutes \\
\hline & $\begin{array}{l}\text { C. was a real Big Man. I remember as a kid seeing him alone in a } \\
\text { canoe or in the bush, sometimes fishing but mostly just checking } \\
\text { up on things. }\end{array}$ & $\begin{array}{l}\text { L. Tungatulum and } \mathrm{R} \text {. } \\
\text { Tipungwuti, } 2011 \text { TLC } \\
\text { records }\end{array}$ \\
\hline
\end{tabular}


Table 1. continued.

\begin{tabular}{|c|c|c|}
\hline \multirow[t]{3}{*}{$\begin{array}{l}\text { Consequence } \\
\text { of poor } \\
\text { manage- } \\
\text { ment } \\
\text { decisions }\end{array}$} & $\begin{array}{l}\text { Tipakalippa families use new introduced steel axes to wantonly cut } \\
\text { trees instead of climbing them for fruits and small animals. } \\
\text { Confronted by Warlapinni families who sought meetings to assert } \\
\text { their better management practices. They successful and rights and } \\
\text { prestige shifted to Warlapinni. }\end{array}$ & C. Kalippa, 2009 TLC records \\
\hline & $\begin{array}{l}\text { Amalgamation of land units from } 13 \text { in } 1980 \text { to } 8 \text { unchanged since } \\
1995 \text { are a landowner response to intrusion and impacts unable to } \\
\text { be managed by scattered and smaller family groups. }\end{array}$ & 1978-2011 TLC minutes \\
\hline & $\begin{array}{l}\text { Large vessel enters Shark Bay } 15 \text { April } 1982 \text { and group land without } \\
\text { permission or consent. Meetings discuss regular nature of these } \\
\text { illegal landings. Wulirankuwila complain they cannot stop these } \\
\text { landings. However meetings reduce the influence of } \\
\text { Wulirankuwila people and the ascendancy of adjacent Yimpinari } \\
\text { people. Wulirankuwila considered to have lost significant } \\
\text { authority and were lesser people. }\end{array}$ & Davis (1983), p. 89 \\
\hline
\end{tabular}

${ }^{*}$ Examples selected as representative of frequent interactions and cultural norms among Tiwis.

consensual redefinition of what is going on" (Venbrux 1995: p. 178). Big Men deal with new information and uncertainty by frequently revising and amending the details of assessments. Thirty-five years of Land Council minutes show continual revisiting and recrafting of numerous decisions. Permission to fish in Tiwi creeks and estuaries, for example, was discussed at over 600 meetings. Seeking and gaining permission remains the consistent principle. For example, meetings of the Land Council through October 2011 considered permission to access areas of Bathurst and Melville islands. The meetings considered a range of new applications from township residents, visitors, contractors, and invitees seeking access for fishing. These deliberations required daily renegotiation of broader social relationships, economic and personal influence, and any number of family and individual advantages.

In all these negotiations, Tiwi managers dealt with pervasive environmental uncertainty by using past experience to guide decisions aimed at attaining satisfactory outcomes. Managers did not attempt explicitly to predict the future, but prediction was implicit in their ongoing responsibility to know where and when critical resources may be accessed.

There were no examples in the materials we examined of decision makers attempting to estimate population sizes or maximize expected value. The Tiwi have no language for numbers and no way of computing probabilistic forecasts. Instead, managers are rewarded when they satisfy family and community demands for reliable access to sufficient resources. Big Men may have many wives only if they can provide surplus (Cook 1994), itself an outcome of reliable judgments (R. Tipungwuti, 2009 TLC records). Venbrux (1995: p. 28) notes how influen- tial Tiwi men sometimes obtain an exceptionally large number of wives. Earlier Pilling (1958: p. 244) stated, "T. was an important Tiwi 'big man.' Like C., with 25 wives, he was a man of importance and prestige."

In the wider Northern Territory community, commercial and recreational fishing is attractive to many people. Recreational fishing is unlicensed, and there are few restrictions on access to waterways and fisheries. Recently, Tiwi decision makers have been under government pressure to abandon their traditional permission principle in favor of government management principles. This suggestion threatens pathways to prestige. In response, landowners have affirmed their interests to protect the traditional principle. Tiwi meetings through 2011 assert that the principle is nonnegotiable but allow exploration of complementary pathways to prestige and influence consistent with permissions and consents. For example, government funding of infrastructure projects may elevate the prestige of land managers in remote areas and relax access rules (Tiwi Land Council Minutes 1978-2011).

Managers monitor the condition of natural resources. Evidence they use (Table 1) includes resource conditions relative to those expected for the season, success of recent harvests, and the presence of habitat or breeding conditions for harvested species such as barramundi. When community members are granted access and harvest the resource, they report the abundance of the resource to the community, thereby validating the manager's decision. Access may be denied on a number of grounds including the time of year; condition of the resource; purpose of expeditions and planned harvest techniques; relationships of people involved, including their indebtedness to particular landowners; and the 
availability of alternatives. For example, when authority was sought for access to barramundi populations that managers considered at risk of depletion, they invoked river closures as a mark of respect for a deceased relative (Goose Creek Closure, 2010 TLC minutes).

To summarize, Tiwi language defines a prestigious land manager, aluwura murrakupuni, as one whose prestige flows from his ability to maintain the resources of land and on whom people can rely for their well-being (Lee and M. Puruntatameri, 2010 TLC records). A manager's status is reinforced and authority over access is reflected in the punitive actions taken toward people who breach protocols (Fig. 1). The feedback loop encourages managers to make decisions that lead to reliably available resources. They are encouraged by the feedback mechanism to monitor and satisfy community demand, thereby increasing the chances that critical resources will be available in the future. The concept of well-being is "crucial to the integrity of (Tiwi) relations with their estates" (Jackson 2004: p. 220) and with each other. Stock depletion of a prized species diminishes the manager's well-being and status by limiting surplus sharing (Davis 1983; Jackson et al. 2011).

\section{The Barramundi Fishery}

There is evidence that harvesting practices over the last 50 years (by non-Tiwi consumers) have depleted barramundi stocks. For example, in 1972 a survey of Melville Island found abundant fish in the river system (Messel et al. 1980: pp. 21-22). Five years later (1977), there were few fish in the same system; researchers speculated the decrease in abundance was the result of illegal poaching and the continuous presence of professional fishers (Messel et al. 1980).

The actions of poachers in the system and the imposition of commercial harvest outside the control of traditional decision makers affect Tiwi management of these systems (Northern Territory Government Department of Resources 2010). Resources are taken independent of the feedback loop (Fig. 1) that links satisficing performance to the individual prestige of the Tiwi decision maker.

Under government management of the barramundi fishery, regulations are triggered by $20 \%$ increases or decreases over 2 years measured in terms of monetary value, catch, or effort and client satisfaction statements (Northern Territory Government Department of Resources 2010). This approach differs from Tiwi decision strategies because it omits personal responsibility and requires quantification of abundance of fish. Currently, professional fisheries in the Northern Territory of Australia harvest about 400,000 saleable (aboveregulation-size catch limit) barramundi (total of $625 \mathrm{t}$ ) annually. Recreational anglers harvest another 100,000, whereas indigenous estuary owners across the same territorial waters may gather up to 44,000 barramundi an- nually (Northern Territory Government Department of Resources 2010). In 2009 the Northern Territory government issued 20 professional licenses to harvest barramundi in Northern Territory waters. In response to declining stocks, the government decreased the number of licenses in 2010 by 4 . Future area closures to commercial barramundi fishing are being considered (Northern Territory Government Department of Resources 2010).

Licenses contribute to effective management; however, noncompliance is a serious problem. There are few incentives to comply with license conditions, apart from the punitive actions government may take if offences are detected. Compliance infractions in the commercial sector include the use of gill nets, fishing in closed waters, exceeding catch limits, retaining undersized barramundi, and fishing in seasonally closed areas (Northern Territory Government Department of Resources 2010).

Potential for conflict between aboriginal landowners in coastal zones and state government arose following a decision of the High Court of Australia (Northern Territory of Australia v. Arnhem Land Aboriginal Land Trust 2008) that allowed continued management and regulation of coastal fishing by the Northern Territory government but granted Tiwi ownership over those resources in streams, creeks, and estuaries surrounding the islands they inhabit. The effect is that fishing is governed by a licensing and management regime that is guided by conventional government regulation. However, access is legally constrained by owners whose decisions aim to satisfy their own aspirations, rather than maximizing expected values or responding to quantitative management triggers.

Decision strategies under uncertainty depend in part on simplicity, itself an important feature of effective searches for satisfactory solutions (Todd \& Gigerenzer 2007). For example, discussion of environmental management issues at a TLC meeting in 2010 led the council to recommend management increase abundance of barramundi in the fishery. Traditional rules of access were reiterated and a restrictive access regime imposed for the restoration of abundant supply of barramundi (TLC minutes 2010).

Introduced tools (fish hooks, axes, and guns), all readily available to Tiwi and capable of increasing harvest efficiency, some for over 200 years, were rarely used. We speculate that none could increase harvest levels sufficiently to supercede the goal to satisfy essential demands and to enhance prestige and influence of the land manager.

\section{Discussion}

Tiwi management strategies address the present exclusively; the future is managed implicitly by the incentives for managers to provide reliable, ongoing access 
to critical resources. There is no analogy in Tiwi culture for foresight or scenario analyses. Both the Tiwi management practices outlined above and adaptivemanagement theory (Linkov et al. 2006) acknowledge that decisions should not foreclose on future options. We speculate that Tiwi decision-making processes and decision strategies accord with the principles of bounded rationality.

We acknowledge that our current analyses are by no means complete. More rigorous, quantitative analyses are necessary to formulate models of specific heuristics, test these, and extend our analysis. For example, careful observational studies and statistical analyses may reveal a broader spectrum of decision-making strategies deployed by Tiwi decision makers, environments to which these strategies are adapted, and situations in which these strategies lead to effective decisions.

There are 3 lessons to be learned from our assessment of Tiwi management systems that may assist in successful use of adaptive management. First, decisions on natural resource management may improve if they are personalized in the sense that they become the responsibility of an identifiable manager who monitors the natural system, is responsible, and is seen to be responsible for the outcomes of decisions. Second, decisions may improve if managers who make good decisions are rewarded in ways that encourage them to manage the system to improve its condition. And finally, decisions may improve if verified performance is related directly to prestige. Our evaluation of Tiwi systems suggests that these social prescriptions are at least as important as are the technical aspects if adaptive management systems are to be deployed effectively for environmental management and conservation in the long term.

\section{Acknowledgments}

We thank Tiwi landowners and the Tiwi Land Council for encouragement over many years in undertaking this work; the CSIRO Darwin and A. Andersen for support and scientific interest to do it, and B. Smith for his interest in the livelihoods of rural Australians. Comments from three anonymous reviewers and the journal's editors have substantially improved the manuscript.

\section{Literature Cited}

Bowdler, S. 1995. Offshore islands and maritime explorations in Australia prehistory. Antiquity 69:945-958.

Cook, J. S. 1994. Culture, control and accountability in community enterprises among the Tiwi. MBA thesis, Northern Territory University, Darwin.

Costello, C., and S. Polasky. 2008. Optimal harvesting of stochastic spatial resources. Journal of Environmental Economics and Management 56:1-18.

Davis, S. 1983. A report on the Bathurst and Melville Island sea clo- sure application. Land Titles Commissioner and Tiwi Land Council Records and Archives, Darwin, Northern Territory.

Gigerenzer, G., and H. Brighton. 2009. Homo heuristicus: why biased minds make better inferences. Topics in Cognitive Science 1:107-143.

Gigerenzer, G., and R. Selten. 2001. Bounded rationality: rethinking rationality. Massachusetts Institute of Technology, Boston.

Gigerenzer, G., R. Hertwig, and T. Pachur, editors. 2011. Heuristics: the foundations of adaptive behavior. Oxford University Press, New York.

Gigerenzer, G., P. M. Todd, and the ABC Research Group. 1999. Simple heuristics that make us smart. Oxford University Press, New York.

Goodale, J. C. 1971. Tiwi wives: a study of the women of Melville Island, north Australia. University of Washington Press, Seattle.

Goose Creek Closure. 2010. Tiwi Land Council, records. National Archives of Australia, Series E1615 27:264.

Hart, C. W. M. 1930. The Tiwi of Melville and Bathurst Islands. Oceania 1:167-180.

Hart, C. W. M, and A. R. Pilling. 1960. The Tiwi of north Australia. Holt, Rinehart and Winston, New York.

Hart, C. W. M., A. R. Pilling, and J. C. Goodale. 1988. The Tiwi of north Australia. Holt, Rinehart and Winston, New York.

Holling, C. S., editor. 1978. Adaptive environmental assessment and management. John Wiley and Sons, London.

Huberman, A. M., and M. B. Miles. 2002. The qualitative researcher's companion. Sage Publications, Thousand Oaks, California.

Jackson, S. 2004. Honour among nations. Treaties and agreements with indigenous people. Maritime agreements and recognition of customary marine tenure in the Northern Territory. Melbourne University Press, Melbourne.

Jackson, S., M. Finn, E. Woodward, and P. Featherstone. 2011. Indigenous socio-economic values and river flows-a summary of research results: 2008-2010. CSIRO Ecosystems Sciences, Darwin, Northern Territory.

Kalippa, C. 2009. Tiwi Land Council, records. National Archives of Australia, Series E1615 24:237-249.

Keith, D. A., T. G. Martin, E. McDonald-Madden, and C. Walters. 2011. Uncertainty and adaptive management for biodiversity conservation. Biological Conservation 144:1175-1178.

Kerinaiua, W. 2010. Tiwi Land Council, records. National Archives of Australia, Series E1615 27:250-263.

King, P. P. 1818. Narrative of a survey of the intertropical and western coasts of Australia performed between the years 1818-1822. BiblioLabs, Charleston, South Carolina.

Lee, J., and M. Puruntatameri. 2010. Tiwi Land Council, records. National Archives of Australia, Series E1615 27:259-264.

Linkov, I., F. K. Satterstrom, G. A. Kiker, T. S. Bridges, S. L. Benjamin, and D. A. Belluck. 2006. From optimization to adaption: shifting paradigms in environmental management and their application to remedial decisions. Integrated Environmental Assessment and Management 2:92-98.

Lyons, J. E., M. C. Runge, H. P. Laskowski, and W. L. Kendall. 2008. Monitoring in the context of structured decision-making and adaptive management. Journal of Wildlife Management 72:16831692.

Marewski, J. N., W. Gaissmaier, and G. Gigerenzer. 2010a. Good judgments do not require complex cognition. Cognitive Processing 11:103-121.

Marewski, J. N., W. Gaissmaier, L. J. Schooler, D. G. Goldstein, and G. Gigerenzer. 2010b. From recognition to decisions: extending and testing recognition-based models for multi-alternative inference. Psychonomic Bulletin \& Review 17:287-309.

Marewski, J. N., and L. J. Schooler. 2011. Cognitive niches: an ecological model of strategy selection. Pscyhological Review, 118:393-437.

Messel, H., A. G. Wells, and W. J. Green. 1980. Surveys of tidal river systems in the Northern Territory of Australia and their crocodile populations. Monograph 6. Pergamon Press, Sydney. 
Nichols, J. D., M. C. Runge, F. A. Johnson, and B. K. Williams. 2007. Adaptive harvest management of North American waterfowl populations: a brief history and future prospects. Journal of Ornithology 148:S343-S349.

Northern Territory Government Department of Resources. 2010. In A. J. Handley, editor. Fisheries status reports 2009. Fishery report 104, p. 17-30, 145-149. Northern Territory Government Department of Resources, Darwin.

Northern Territory of Australia v. Arnhem Land Aboriginal Land Trust. 2008. High Court of Australia 2008 judgment summaries. Available from www.hcourt.gov.au (accessed March 2012).

Peterson, N., and J. Taylor. 1998. Demographic transition in a huntergatherer population: the Tiwi case, 1929-1996. Australian Aboriginal Studies 1:11-27.

Pilling, A. R. 1958. Law and feud in an aboriginal society of north Australia. Wayne State University, Detroit.

Pilling, A. R. 1978. A socio-cultural approach to homicide. Wayne State University, Detroit.

Punt, A. E., and R. Hilborn. 1997. Fisheries stock assessment and decision analysis: the Bayesian approach. Reviews in Fish Biology and Fisheries 7:35-63.

Pupungamirri, J. B. 1983. Tiwi Land Council, records. National Archives of Australia, Series E1615 3:47-75.

Pupungamirri, J. B. 2001. Tiwi Land Council, records. National Archives of Australia, E1615 11:216-221.

Puruntatameri, J. 1980, 1981. Tiwi Land Council, records. National Archives of Australia, Series E1615 2:1-46.

Puruntatameri, J. 1995. Tiwi Land Council, records. National Archives of Australia, Series E1615 6:146-174.

Sim, R., and L. A. Wallis. 2008. Northern Australian offshore island use during the Holocene. Australian Archaeology 67:95-106.

Simon, H. 1991. Bounded rationality and organizational learning. Organization Science 2:125-134.

Simon, H. A. 1978. Rational decision-making in business organisations. Nobel Memorial Lecture, 8 December, 1978. A. Lindbeck, editor.
Nobel Lectures in Economic Sciences 1969-1980. The Sveriges Riksbank (Bank of Sweden) Prize in Economic Sciences in Memory of Alfred Nobel. University of Stockholm, 1992, 343-368.

Simon, H. A., J. C. Shaw, and A. Newell. 1958. The processes of creative thinking. University of Colorado, Boulder.

Smith, A. D. M., E. J. Fulton, A. J. Hobday, D. C. Smith, and P. Shoulder. 2007. Scientific tools to support the practical implementation of ecosystem-based fisheries management. ICES Journal of Marine Science 64:633-639.

Swaardecroon, H. K., C. S. Castelijn, and J. S. Craine. 1859. A written detail of the discoveries and noticeable occurrences in the voyage of the Fluyt Vossenbosch, the sloop D'Waijer and the Patsjallang Nova Hollandia. Pages $168-170$ in R. H. Major, editor. Early voyages to Terra Australis. Now called Australia. Hakluyt Society, London.

Tipungwuti, J. 1995. Tiwi Land Council, records. National Archives of Australia, Series E1615 6:146-174.

Tipungwuti, R. 2009. Tiwi Land Council, records. National Archives of Australia, Series E1615 24:237-249.

Todd, P. M., and G. Gigerenzer. 2007. Mechanisms of ecological rationality: heuristics and environments that make us smart. Pages 203-207 in R.I.M. Dunbar, and L. Barret, editors. The Oxford handbook of evolutionary psychology. Oxford University Press, New York.

Tungatulum, L., and R. Tipungwuti. 2011. Tiwi Land Council, records. National Archives of Australia, Series E1615 28:295-304.

Venbrux, E. 1995. A death on the Tiwi Islands-conflict, ritual and social life in an Australian Aboriginal community. Cambridge University Press, Cambridge, United Kingdom.

Walters, C. J., and C. S. Holling. 1990. Large-scale management experiments and learning by doing. Ecology 71:2060-2068.

Wightman, G. 2001. Tiwi plants and animals. Northern Territory Government, Tiwi Land Council. Square Peg Design, Perth.

Wonaeamirri, M. 2003. Tiwi Land Council, records. National Archives of Australia, Series E1615 13:226-229. 